\title{
LAHAN BASAH BUATAN SEBAGAI PENGOLAH LIMBAH CAIR DAN PENYEDIA AIR NON-KONSUMSI
}

\author{
Siti Qomariyah ${ }^{1}$, Sobriyah $^{2}$, Koosdaryani $^{3}$, dan Adi Yusuf Muttaqien ${ }^{4}$ \\ ${ }^{1}$ Jurusan Teknik Sipil, Universitas Sebelas Maret, Jl. Ir. Sutami 36 A Surakarta \\ Email: siti.qomariyah@ft.uns.ac.id \\ ${ }^{2}$ Jurusan Teknik Sipil, Universitas Sebelas Maret, Jl. Ir. Sutami 36 A Surakarta \\ Email: sobriyah@ft.uns.ac.id \\ ${ }^{3}$ Jurusan Teknik Sipil, Universitas Sebelas Maret, Jl. Ir. Sutami 36 A Surakarta \\ Email: koosdaryani@gmail.com \\ ${ }^{4}$ Jurusan Teknik Sipil, Universitas Sebelas Maret, Jl. Ir. Sutami 36 A Surakarta \\ Email: adiyusuf2013@gmail.com
}

\begin{abstract}
ABSTRAK
Pencemaran air telah menjadi issu global terutama di kota-kota besar. Instalasi pengolah air limbah konvensional membutuhkan biaya tinggi. Lahan basah buatan yang lebih fleksibel dan ekonomis mulai banyak diterapkan sebagai teknologi hijau untuk mengolah limbah cair. Tulisan ini menguraikan tipe dan komponen lahan basah buatan dan menyajikan hasil uji eksperimen pengolahan limbah cair jenis greywater. Lahan basah buatan dalam studi ini menggunakan media filter pasir dan kerikil serta tanaman air jenis Cyperus papyrus. Pengolahan greywater terhadap parameter TSS, pH, BOD, COD, Minyak \& Lemak, dan Deterjen menghasilkan prosentase penyisihan berkisar antara 95,47\% - 99,89\%. Besaran konsentrasi polutan di oulet, yang merupakan hasil pengolahan greywater, memenuhi standar baku mutu Peraturan Menteri Lingkungan Hidup no. 5 tahun 2014, dan Peraturan Pemerintah no. 82 tahun 2001 kelas IV sebagai air untuk mengairi tanaman dan atau peruntukan lain yang mensyaratkan mutu air yang sama dengan kegunaan tersebut.
\end{abstract}

Kata kunci: lahan basah buatan, greywater, penyediaan air, teknologi hijau

\section{PENDAHULUAN}

Isu global yang sedang berkembang terkait masalah air adalah pencemaran air, kekurangan air, dan degradasi sumber-sumber air. Hal tersebut menjadi problem serius akibat akumulasi aktifitas manusia yang cenderung merusak lingkungan dan meningkatnya jumlah penduduk terutama di negara-negara berkembang (Vymazal, 2010; Wu et al., 2015). Di banyak negara berkembang, 90\% limbah cairnya dibuang langsung ke sungai, danau, atau laut tanpa diolah terlebih dahulu (UN Habitat, 2008). Di Indonesia, sungai-sungai telah mengalami pencemaran. Pada tahun 2015, hampir 68\% kualitas air sungai di 33 provinsi di Indonesia dalam status tercemar berat (KLHK, 2016). Penyumbang terbesar (60\%) pencemaran air pada sistim sumber-sumber air (air permukaan dan air tanah) di kotakota di Indonesia adalah akibat limbah domestik, karena limbah (jenis greywater) langsung dibuang ke selokan tanpa pengolahan (treatment) terlebih dahulu sebelum masuk ke sungai-sungai atau badan air (Hendrawan et al., 2013). Hal tersebut diperkuat oleh WWAP (2012) yang menyatakan bahwa limbah domestik penduduk kota merupakan sumber pencemaran yang signifikan. Untuk limbah dometik jenis blackwater (limbah kakus), TWB (2013) melaporkan bahwa di Indonesia rumah-rumah penduduk kota dan area bisnis telah menggunakan septicktank untuk pengolahannya. Meskipun sudah ada kriteria desain septicktank, namun tidak adanya 'enforcement' terhadap pembuatan septicktank yang memenuhi syarat standar teknis, maka septicktank berpotensi tidak optimal (retal/pecah). Hal tersebut mengakibatkan cairan dalam septicktank merembes dan mencemari air tanah. Mengingat air sungai dan air tanah merupakan sumber air bersih yang dikonsumsi mayoritas masyarakat, maka pencemaran sumber air tersebut membahayakan kesehatan masyarakat dan lingkungan hidup.

Instalasi Pengolah Air Limbah (IPAL) dengan sistim terpusat (centralized) telah dibangun di 12 kota di Indonesia (Medan, Prapat, Jakarta, Bandung, Cirebon, Yogyakarta, Banjarmasin, Surakarta, Bali, Balikpapan, Tangerang, dan Batam), namun ke 12 IPAL tersebut baru melayani 10\% dari penduduk Indonesia (Hendrawan et al., 2013). IPAL sistim terpusat atau sistim konvensional tersebut berbiaya tinggi karena membutuhkan biaya besar dalam pengadaan lahan, pembangunan kolam-kolam aerasi, pengolah lumpur, rotasi-biologi, pengadaan mesin-mesin mekanik, biaya operasional, biaya energy, memerlukan operator terlatih, biaya sistim perpipaan, dan membutuhkan perencanaan dan 
pembangunan yang relatif lama. Sistim konvensional dan terpusat tersebut sangat mahal bagi negara berkembang yang selama ini pembangunannya mengandalkan bantuan/hutang dari luar negeri.

Di negara berkembang, fasilitas pengolahan limbah hanya dapat berkelanjutan dengan kriteria biaya ekonomis dan menggunakan teknologi tepat guna; dan sistim Lahan Basah Buatan atau Constructed Wetland System (CWs) merupakan teknologi pengolahan limbah yang memenuhi kriteria tersebut (Kivaisi, 2001). CWs berbiaya relatif rendah dan berwawasan lingkungan yang berdasarkan pada konsep lahan basah alami (Kadlec dan Wallace, 2009). Mengingat praktek pembuangan limbah domestik di Indonesia mayoritas sudah memisahkan antara blackwater dan greywater, maka pengolahan greywater berpotensi untuk dapat dilakukan di rumah-rumah tinggal, apartemen, maupun di kawasan bisnis/perkantoran. Pengolahan dan pemanfaatan kembali greywater dengan menerapkan CWs sebagai bagian dari konsep ekologi sanitasi (ecosan) masih merupakan konsep baru, namun hal tersebut sudah diterapkan di negara-negara maju (Hoffmann et al., 2011). Di Indonesia, penerapan CWs tersebut belum banyak dilakukan. Tulisan ini menguraikan tipe dan komponen CWs dan menyajikan hasil uji eksperimen pengolahan greywater yang telah dilakukan.

\section{TINJAUAN PUSTAKA}

\section{Greywater}

Greywater adalah limbah cair dari semua aktifitas rumah / bangunan selain dari toilet (kakus). Karaktersitik greywater dipengaruhi oleh gaya hidup penghuni rumah seperti budaya memasak/makanan, volume penggunaan air, dan jenis bahan-bahan pembersih rumah tangga yang digunakan (Erickson et al., 2002). Berdasar riview Pidou, M. et al (2007) terhadap 64 pengolahan greywater di negara-negara maju, pemanfaatan hasil olahan greywater adalah untuk penyiraman tanaman, penggelontoran toilet, pembersihan di luar rumah, laundry, dan infiltrasi.

\section{Lahan basah buatan (constructed wetlands $=$ CWs)}

CWs merupakan sistim enjinering pengolahan limbah cair yang menirukan proses alam dalam memperbaiki kualitas air dengan menyisihkan polutan yang terkandung di dalam air limbah melalui proses fisik (penyaringan dan sedimentasi), proses biologi (pertumbuhan mikroba dan tanaman air), dan proses mekanik (Kadleck dan Knight, 1996). Proses dinamis yang terjadi di dalam CWs melibatkan beberapa unsur antara lain: air, media filter atau substrate (pasir, kerikil, atau media filtrasi lainnya), tanaman air (macrophyte), litter (daun atau batang tanaman yang gugur), dan beragam mikroorganisme (Kadlec dan Wallace, 2009). Dengan demikian, CWs merupakan sistim yang komplek dan sulit dipahami karena proses fisik, biologi, mekanik dan bahkan kimia terjadi secara aktif dan masing-masing komponen saling mempengaruhi, maka CWs selama ini disebut sebagai "black boxes" (Langergraber et al., 2013). Kelebihan teknologi CWs dibanding teknologi lainnya adalah mengolah greywater sekaligus menciptakan estetika lingkungan, yang dikenal dengan istilah ecosan (ekologi sanitasi), dimana teknologi ini menggunakan tanaman air sebagai salah satu media pengolahan limbah (Hoffmann et al., 2011). Dalam beberapa literature, istilah lain dari constructed wetland $(\mathrm{CW})$ antara lain: man-made, engineered, artificial, atau treatment.

Sistim CWs pertama kali dikembangkan oleh ilmuwan Jerman: Dr. K. Seidel - pada dekade 1960 (Vymazal, J., 2008). Hingga saat ini sistim CWs telah diterapkan di beberapa negara maju antara lain Denmark (Brix dan Arias, 2007), Jerman (Hoffmann et al., 2011), dan beberapa negara maju lainnya (Vymazal, J., 2010). Sistim CWs belum diterapkan secara persuasif di negara-negara berkembang (khususnya di negara beriklim tropis dan sub-tropis) dimana pengendalian polusi dan pelestarian lingkungan hidup belum banyak mendapat perhatian. Namun, di negaranegara berkembang seperti Mesir (Elzein et al., 2016), Mexico (Merino et al., 2015), dan China (Wu et al., 2015), beberapa penelitian dan penerapan CWs sudah mulai dipublikasikan. Di Indonesia, penerapan sistim CWs untuk pengolahan greywater belum banyak diketahui.

\section{Komponen CWs}

Komponen CWs terdiri dari air, media lolos air (substrate), tanaman air, dan mikroorganisme yang tumbuh di dalam lahan basah. Komponen air menghubungkan semua fungsi di dalam lahan basah, dan efisiensi pengolahan limbah di CWs tergantung pada sifat-sifat air (limbah cair) yang bersangkutan. Komponen media lolos air yang digunakan biasanya substrate alami seperti pasir, kerikil, atau pecahan batu. Substrate tersebut disyaratkan bersih, keras, durabel, dan tidak berubah bentuk untuk menjaga permeabilitas tanah dalam jangka panjang (USEPA, 2000). Fungsi substrate antara lain sebagai media tumbuh bagi tanaman air, mensuport transformasi biologi dan kimia, memfasilitasi pergerakan aliran limbah, menjadi media pertumbuhan microorganisme dengan membentuk biofilm di permukaan substrate, membantu menyisihkan partikel halus melalui sedimentasi, adsorbsi, dan filtrasi (Kadlec and 
Wallace, 2009). Lapisan media bertindak sebagai filter mekanik dan filter biologi. Filter mekanik menyaring polutan suspended dan microbial solid, sedangkan polutan organik diserap oleh biofilm. Melalui proses biologi, semua kandungan organik dihancurkan oleh mikroorganisme yang tumbuh pada permukaan partikel tanah/pasir dan akarakar tanaman air (Hoffmann et al., 2011). Komponen tanaman air merupakan komponen utama dalam ekosistim lahan basah di alam, termasuk lahan basah buatan (Vymazal, 2011). Karena keberadaan tanaman air tersebut, sistim lahan basah (CWs) disebut dengan green technology. Meskipun tanaman air merupakan komponen utama di dalam ekosistim lahan basah, pengolahan limbah mencakup beragam proses fisik, kimia, biologi, dan proses diantara tanaman-media substrate-mikroorganisme.

Tanaman yang digunakan dalam CWs adalah tanaman yang terdapat di perairan atau lahan basah seperti di bantaran sungai atau rawa. Terdapat 4 kelompok tanaman air berdasarkan bentuk atau lokasi pertumbuhannya, yaitu: emergent plants, floating leaved plants, submerged plants, and free floating plants. Tanaman emergent tumbuh pada tanah yang jenuh air. Sebagian dari batang tanaman berada diatas tanah dan terendam air, sisanya di udara bebas. Tanaman floating leaved mempunyai akar di tanah yang submerged, semua batangnya berada di dalam air. Tanaman submerged tumbuh dengan batang \& daun di dalam air. Tanaman free floating tidak berakar di media tanah. (Kadlec and Wallace, 2009). Berdasarkan Vymaxal (2011), tanaman tipe emerged yang paling sering digunakan dalam CWs tipe sub-surface flow adalah Phragmites australis (di Europe, Canada, Australia, Asia, dan Africa), kemudian tanaman jenis Typha (di America Utara, Australia, East Asia, dan Africa. Menurut Hoffmann et al. (2011), jenis tanaman air yang bisa digunakan di daerah beriklim hangat seperti Asia, Afrika, Amerika Selatan antara lain jenis Papyrus (Cyperus papyrus), Umbrella (Cyperus albostriatur), Dwarf papyrus (Cyperus haspens), Small bamboo, Typa latifolia, Canna lily, Calla lily, dan jenis Vetifer. Dari jenis tanaman air tersebut yang bersifat tanaman dekoratif adalah Cyperus papyrus, Bamboo, dan Canna lily, Calla lily.

\section{Tipe lahan basah buatan}

Terdapat dua macam tipe lahan basah, yaitu: Free Water Surface (FWS) atau Surface Flow (SF), dan SubSurface Flow (SSF). Pada sistim SF, aliran air berada di atas permukaan tanah. Pada sistim SSF, permukaan air berada di bawah muka tanah. Berdasarkan arah aliran limbah, terdapat dua tipe SSF, yaitu arah horizontal dan arah vertikal (Kadlec dan Wallace, 2009) seperti terlihat pada gambar berikut.

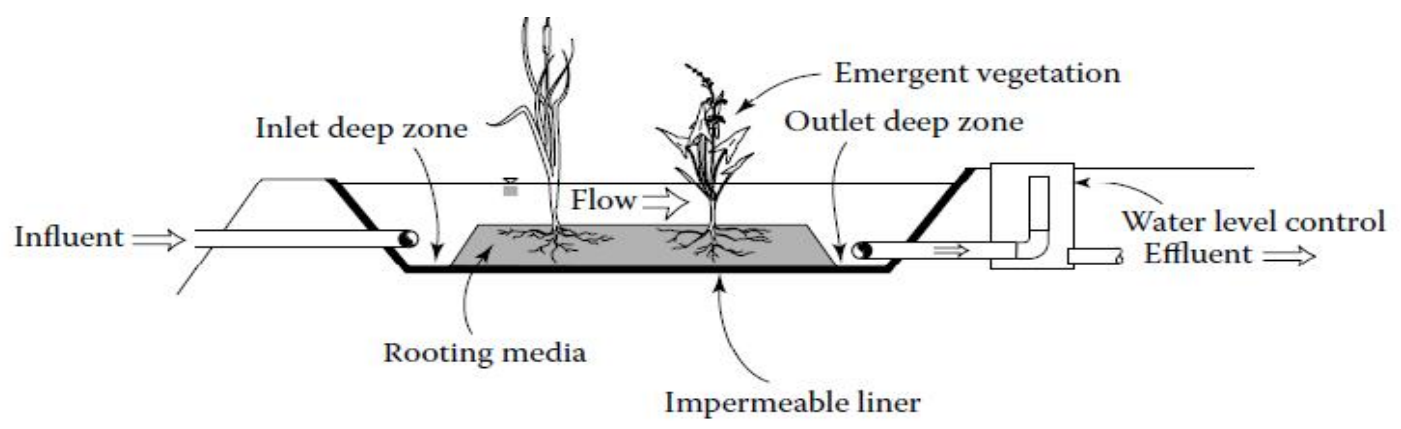

Gambar 1. Tipe Surface Flow (Kadlec \& Wallace, 2009)

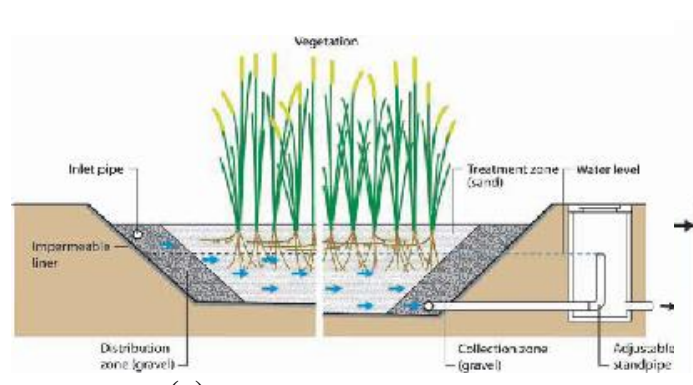

(a)

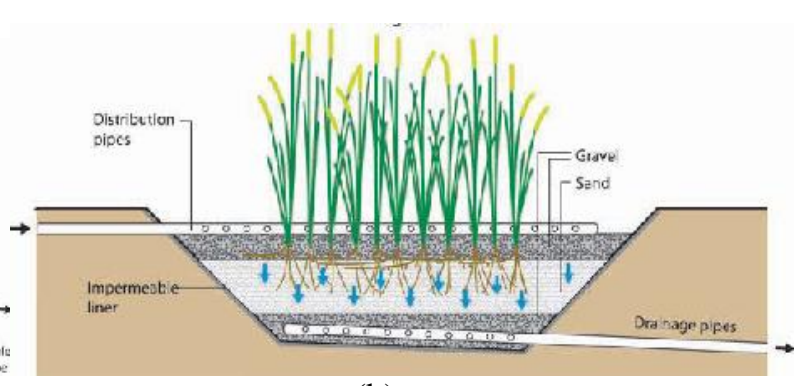

(b)

Gambar 2. (a) Tipe Horizontal SubSurface Flow; (b) Tipe Vertical SubSurface Flow (Morel \& Diener, 2006) 
Beberapa parameter polutan dan proses penyisihannya di dalam CWs disajikan pada tabel berikut (Hoffmann et al., 2011).

Tabel 1. Polutan dan proses penyisihannya dalam CWs

\begin{tabular}{|c|c|}
\hline Polutan & Proses Penyisihan \\
\hline Suspended solid (TSS) & - $\quad$ Filtrasi, dekomposisi oleh bakteri sepanjang masa retensi \\
\hline $\begin{array}{l}\text { Material organik (diukur } \\
\text { sebagai COD/BOD) }\end{array}$ & $\begin{array}{l}\text { - Penyisihan material organik oleh proses sedimentasi atau filtrasi } \\
\text { kemudian menjadi BOD terlaut } \\
\text { - Organik terlarut terperangkap pada biofilm dan disisihkan melalui } \\
\text { proses degradasi dengan adanya bakteri (biofilm di akar-akar tanaman, } \\
\text { batang, dan partikel pasir, dll.) }\end{array}$ \\
\hline Nitrogen & $\begin{array}{l}\text { - Nitrifikasi dan denitrifikasi pada biofilm, dan diserap oleh tanaman } \\
\text { (pengaruhnya terbatas) }\end{array}$ \\
\hline Phosporus & $\begin{array}{l}\text { - Retensi/adsorpsi di tanah dan penyisiran tanaman (pengaruhnya } \\
\text { terbatas) }\end{array}$ \\
\hline Pathogen & $\begin{array}{l}\text { - Filtrasi, adsorpsi, dimakan oleh protozoa, mati dalam masa retensi, } \\
\text { degradasi oleh ultra violet }\end{array}$ \\
\hline Logam berat & - $\quad$ Sedimentasi dan adsorpsi \\
\hline Kontaminan organik lain & - Adsorpsi oleh biofilm, dekomposisi dalam masa retensi \\
\hline
\end{tabular}

Sumber: Hoffmann et al., 2011

\section{Desain luas permukaan CWs}

Desain luas permukaan CWs yang berdasarkan pendekatan empirik (rules of thumb), yaitu luas permukaan ( $\mathrm{m}^{2}$ luas) per $\mathrm{m}^{3}$ limbah dan dinyatakan dengan per person equivalent $(\mathrm{PE})$ antara lain terdapat pada beberapa sumber sebagai berikut:

Tabel 2. Parameter desain luas permukaan CWs (m2/PE) berdasar pendekatan empirik

\begin{tabular}{llll}
\multicolumn{1}{c}{ Sumber } & \multicolumn{1}{c}{$\begin{array}{c}\text { CWs } \\
\text { Horizontal }\end{array}$} & \multicolumn{1}{c}{$\begin{array}{c}\text { CWs } \\
\text { Vertikal }\end{array}$} & \multicolumn{1}{c}{ Keterangan } \\
\hline Brix and Arias (2005) & & $<3,2$ & Guide di Denmark \\
UN-Habitat (2008) & $1-2$ & $0,8-1,5$ & - \\
Hoffman et al., (2011) & 3 & 1,2 & Iklim sedang $>20^{\circ} \mathrm{C}$ \\
& 8 & 4 & Iklim dingin $<10^{\circ} \mathrm{C}$ \\
\hline
\end{tabular}

Luas permukaan CWs yang dihitung berdasar simple first-order decay models yang mengacu pada persamaan yang digunakan dalam desain limbah domestik (wastewater: greywater+blackwater) pada sub-surface flow (SSF) diturunkan oleh Kadlec and Knight (1996) sebagai Persamaan 1).

$$
A_{s}=\frac{365}{k} \times \ln \frac{\left(C_{8}-C^{*}\right)}{\left(C_{i}-C^{*}\right)}
$$

dengan $\mathrm{A}_{\mathrm{s}}=$ luas area wetlands $\left(\mathrm{m}^{2}\right), \mathrm{Q}=$ rerata debit aliran limbah $\left(\mathrm{m}^{3} / \mathrm{hr}\right), \mathrm{C}_{\mathrm{i}}=$ influen BOD $(\mathrm{mg} / \mathrm{l}), \mathrm{C}_{\mathrm{e}}=$ target efluen $\mathrm{BOD}_{5}(\mathrm{mg} / \mathrm{l}), \mathrm{C}^{*}=$ konsentrasi polutan acuan $\mathrm{BOD}=3,5+0,053 \mathrm{C}_{\mathrm{i}}$ dan $\mathrm{k}=$ konstanta laju pada tahap pertama $(\mathrm{m} / \mathrm{hr})$.

\section{Pre-Tretament}

Sebelum greywater diolah di dalam CW, pre-treatment diperlukan untuk mengendapkan suspended solid atau partikel-partikel besar seperti seperti sobekan kertas tisu, remahan sisa makanan, dan lain-lain. Pre-treatment dilakukan untuk menghindari adanya penyumbatan karena penggumpalan (clogging) partikel-partikel kasar tersebut dan dapat dilakukan secara mekanik dengan menggunakan screen, atau saringan dari pasir, atau grease trap (Hoffmann et al., 2011).

\section{Penyisihan Pathogen dalam CWs}


Penyisihan semua unsur polutan telah dilakukan di negara-negara maju, namun di negara berkembang masih mengutamakan penyisihan pada unsur pathogen -yang biasa diindikasikan dengan tingkat bakteri coli-, kandungan organik, dan nutrient (Kivaisi, 2001). Penyisihan bakteri coli mencapai lebih besar dari 99\% merupakan criteria desain CWs yang diinginkan (Kadlec dan Knight, 1996). Penyisihan pathogen, unsure organik, dan nutrient dari limbah domestik merupakan kebutuhan mendasar bagi terciptanya sistim sanitasi kota yang bersih dan lingkungan hidup yang aman bagi kesehatan masyarakat (Langergraber 2013).

\section{METODE PENELITIAN}

Penelitian di lakukan di Kota Surakarta selama bulan Juli sampai dengan Desember 2015. Sampling greywater dari rumah tunggal dan perumahan dilakukan dengan metode pengambilan contoh air limbah berdasar SNI 6989.59 2008. Uji kualitas sampel greywater dilakukan di laboratorium untuk mengetahui karakteristik limbah greywater rumah tangga tersebut.

Penelitian eksperimental pengolahan greywater dilakukan di halaman percobaan rumah tunggal di Kalurahan Manahan, Surakarta. Sistim lahan basah buatan dibuat dengan menggunakan CWs tipe horizontal subsurface flow dengan dimensi $1.7 \mathrm{~m} \times 0.7 \mathrm{~m} \times 0.7 \mathrm{~m}$ (panjang x lebar x tinggi). Bak reaktor CWs tersebut dibuat dari material galvanum. Media substrates terdiri dari material pasir dan kerikil dengan kedalaman media 50cm. Media kerikil dengan diameter $1-3 \mathrm{~cm}$ diatur sepanjang $20 \mathrm{~cm}$ pada zona inlet dan outlet. Media pasir dengan diameter $\leq$ dari 0,5 $\mathrm{cm}$ dengan permeability $5.48 \times 10^{-5} \mathrm{~cm} /$ detik mengisi zona pertumbuhan tanaman air sepanjang $130 \mathrm{~cm}$. Tanaman air yang digunakan adalah jenis Cyperus papyrus yang ditanam dengan interval $25 \mathrm{~cm}$. Sebelum dimasukkan ke dalam reaktor CWs, pasir dan kerikil serta akar-akar tanaman dicuci untuk menghilangkan unsur-unsur bawaan dari lokasi asal. Proses pertumbuhan tanaman dan penyesuain di lingkungan baru (di dalam CWs) dilakukan hingga tanaman tumbuh $\pm 60 \mathrm{~cm}$. Proses aklimatisasi tanaman terhadap greywater di dalam bak CWs dilakukan dengan mengalirkan greywater dengan konsentrasi yang bertahap, dari 25\% hingga 100\% selama empat minggu. Sebelum dialirkan ke dalam bak CWs, greywater yang berasal dari rumah tunggal secara mekanik dimasukkan ke dalam tanki sedimentasi. Dengan masa tinggal limbah di dalam bak CWs (hydraulic retention time) selama satu hari, dua hari, dan tiga hari, sampling dilakukan terhadap influen (aliran masuk ke CWs) dan effluen (aliran keluar dari CWs). Kualitas sampel-sampel greywater tersebut kemudian di uji di laboratoruim UPT FMIPA UNS Surakarta dan Laboratorium Balai Besar Teknik Kesehatan Lingkungan \& Pengendalian Penyakit (BBTKL\&PP) Yoyakarta. Parameter uji meliputi Temperatur, Total Suspended Solid (TSS), pH, Minyak dan Lemak, Biochemical Oxygen Demand $\left(\mathrm{BOD}_{5}\right)$, Chemical Oxygen Demand (COD), dan Deterjen. Kualitas hasil olahan greywater berdasar uji laboratorium dibandingkan dengan Peraturan Menteri Lingkungan Hidup RI nomor 5 tahun 2014 tentang Baku Mutu Air Limbah, dan Peraturan Pemerintah nomor 82 tahun 2001 tentang Pengelolaan Kualitas Air dan Pengendalian Pencemaran Air.

\section{HASIL DAN PEMBAHASAN}

Kualitas greywater yang berasal dari dua perumahan dan satu rumah tunggal di Kota Surakarta dapat dilihat pada tabel berikut.

Tabel 3. Parameter greywater pada perumahan dan rumah tunggal di Surakarta

\begin{tabular}{cccrrrr}
\hline Parameter & Sat & $\begin{array}{c}\text { Baku Mutu } \\
\text { *PM LH }\end{array}$ & $\begin{array}{c}\text { Baku Mutu } \\
\text { **PP kls IV }\end{array}$ & $\begin{array}{c}\text { Perum. } \\
\text { Fajar Indah }\end{array}$ & $\begin{array}{c}\text { Perum. } \\
\text { Nilagraha }\end{array}$ & $\begin{array}{r}\text { Rumah di } \\
\text { Manahan }\end{array}$ \\
\hline Temperatur & ${ }^{\circ} \mathrm{C}$ & - & & 26,1 & 26,1 & 26,00 \\
TSS & $\mathrm{mg} / 1$ & 100 & & 775,0 & 45,0 & $7.435,00$ \\
pH & - & $6-9$ & $5-9$ & 6,6 & 6,5 & 8,92 \\
Minyak/lemak & $\mathrm{mg} / 1$ & 10 & & 4,8 & 2,6 & 8,60 \\
BOD & $\mathrm{mg} / 1$ & 100 & 12 & 120,0 & 40,2 & $4.089,00$ \\
COD & $\mathrm{mg} / 1$ & - & 100 & 325,7 & 112,8 & $11.686,00$ \\
\hline
\end{tabular}

Keterangan:

*Peraturan Peraturan Menteri Lingkungan Hidup RI nomor 5 tahun 2014 tentang Baku Mutu Air Limbah,

**Peraturan Pemerintah nomor 82 tahun 2001 tentang Pengelolaan Kualitas Air dan Pengendalian Pencemaran Air (kelas IV).

Tabel diatas menunjukkan bahwa greywater di Perumahan Fajar Indah dan rumah tunggal di Kalurahan Manahan mengandung polutan TSS dan BOD yang melebihi standar baku mutu PerMen. LH no.5 tahun 2014. Konsentrasi BOD yang rendah di Perumahan Nilagraha disebabkan titik sampling berada cukup jauh dari outlet perumahan. Berdasar Peraturan Pemerintah no. 82 tahun 2001, kandungan COD di tiga lokasi tersebut melebihi batas baku mutu 
air Kelas IV (lebih besar dari $100 \mathrm{mg} / \mathrm{l}$ ), dengan demikian limbah greywater tersebut tidak dapat digunakan langsung sebagai air untuk mengairi tanaman. Kualitas ke tiga sampel greywater tersebut sesuai dengan hasil pemantauan kualitas air sungai-sungai di Kota Surakarta yang dilakukan oleh Badan Lingkungan Hidup Kota Surakarta yang menghasilkan bahwa air sungai-sungai di dalam Kota Surakarta mengalami pencemaran (BLH, 2015).

Kinerja sistim pengolahan greywater dengan CWs tipe horizontal dan prosentase penyisihan polutan dapat dilihat pada tabel berikut. Uji laboratorium dilakukan terhadap sampel greywater di inlet (sebelum diolah) dan di outlet (setelah diolah) dalam CWs dengan HRT (hydraulic retention time) selama 1 hari, 2 hari, 3 hari.

Tabel 4. Parameter greywater di inlet \& di outlet dengan HRT 1, 2, dan 3 hari

\begin{tabular}{|c|c|c|c|c|c|c|c|c|c|c|}
\hline Parameter & Sat & $\begin{array}{c}\text { Mutu } \\
\text { PM LH }\end{array}$ & $\begin{array}{c}\text { Mutu PP } \\
\text { kls IV }\end{array}$ & Inlet & $\begin{array}{l}\text { Outlet } \\
1 \text { hari }\end{array}$ & $\begin{array}{c}\text { Penyisihan } \\
\% \\
\end{array}$ & $\begin{array}{l}\text { Outlet } \\
2 \text { hari }\end{array}$ & $\begin{array}{c}\text { Penyisihan } \\
\% \\
\end{array}$ & $\begin{array}{l}\text { Outlet } \\
3 \text { hari }\end{array}$ & $\begin{array}{c}\text { Penyisihan } \\
\%\end{array}$ \\
\hline TSS & $\mathrm{mg} / \mathrm{l}$ & 100 & & 280,00 & 0,00 & 100,00 & 5,00 & 98,21 & 5,00 & 98,21 \\
\hline $\mathrm{pH}$ & - & $6-9$ & $5-9$ & 6,29 & 6,23 & & 6,12 & & 6,25 & \\
\hline BOD & $\mathrm{mg} / \mathrm{l}$ & 100 & 12 & 68,90 & 2,79 & 95,95 & 1,85 & 97,31 & 1,42 & 97,93 \\
\hline COD & $\mathrm{mg} / \mathrm{l}$ & - & 100 & 527,93 & 19,17 & 96,36 & 14,17 & 97,32 & 3,83 & 99,27 \\
\hline $\mathrm{NH}_{3}-\mathrm{N}$ & $\mathrm{mg} / \mathrm{l}$ & - & - & 11,13 & 0,11 & 99,01 & 0,11 & 99,01 & 0,02 & 99,82 \\
\hline
\end{tabular}

Hasil pengolahan greywater tersebut diatas menunjukkan bahwa sebelum diolah, parameter TSS melebihi baku mutu. Setelah diolah selama 1 hari, 2 hari, dan 3 hari, penyisihan TSS berturut-turut dapat mencapai 100\%, 98,21\%, dan $98,21 \%$. TSS di outlet yang jauh dibawah $100 \mathrm{mg} / \mathrm{l}$ menunjukkan CWs tersebut sangat efisien menyisihkan material suspended solid. Penyisihan BOD, COD, dan amoniak $\left(\mathrm{NH}_{3}-\mathrm{N}\right)$ dapat mencapai lebih dari $95 \%$. Konsentrasi BOD dan COD di outlet memenuhi standar baku mutu dan masuk kriteria sebagai air yang dapat digunakan untuk mengairi tanaman; bahkan, masuk kriteria air kelas II (BOD < 3mg/l dan COD < 25mg/l), yaitu air untuk kebutuhan mengairi tanaman, sarana dan prasarana rekreasi air, budidaya ikan, dan peternakan.

Mengacu pada hasil yang tidak jauh berbeda antara HRT 1 hari, 2 hari, dan 3 hari tersebut di atas, pengujian selanjutnya menggunakan HRT selama 1 hari dengan tenggang waktu istirahat selama kurang lebih 12 hari. Hal tersebut diperlukan untuk membersihkan media dari bekas limbah sebelumnya. Hasil pengujian disajikan pada tabel berikut.

Tabel 5. Parameter greywater sebelum di olah \& setelah diolah dengan HRT 1 hari

\begin{tabular}{|c|c|c|c|c|c|c|c|c|c|c|c|c|}
\hline \multirow[t]{2}{*}{ Parameter } & \multirow[t]{2}{*}{ Sat } & \multirow[t]{2}{*}{$\begin{array}{c}\text { Mutu } \\
\text { PM } \\
\text { LH } \\
\end{array}$} & \multirow[t]{2}{*}{$\begin{array}{c}\text { Mutu } \\
\text { PP kls } \\
\text { IV }\end{array}$} & \multicolumn{3}{|c|}{$\begin{array}{c}\text { Uji ke-1 } \\
3 \text { \& } 4 \text { Nov'15 }\end{array}$} & \multicolumn{3}{|c|}{$\begin{array}{c}\text { Uji ke-2 } \\
15 \& 16 \text { Nov'15 }\end{array}$} & \multicolumn{3}{|c|}{$\begin{array}{c}\text { Uji ke-3 } \\
26 \& 27 \text { Nov'15 }\end{array}$} \\
\hline & & & & Inlet & Outlet & $\%$ & Inlet & Outlet & $\%$ & Inlet & Outlet & $\%$ \\
\hline Temp. & ${ }^{\circ} \mathrm{C}$ & - & - & 26,90 & 27,20 & & 23,20 & 24,20 & & 26,40 & 26,30 & \\
\hline TSS & $\mathrm{mg} / \mathrm{l}$ & 100 & & 461,00 & 2,00 & 99,56 & 238,00 & 2,00 & 99,16 & 222,00 & 10,00 & 95,47 \\
\hline $\mathrm{Ph}$ & - & $6-9$ & $5-9$ & 5,17 & 6,89 & & 6,10 & 6,50 & & 5,29 & 6,82 & \\
\hline BOD & $\mathrm{mg} / \mathrm{l}$ & 100 & 12 & 496,00 & 9,49 & 98,08 & 850,20 & 17,20 & 97,98 & 528,70 & 2,19 & 99,5 \\
\hline COD & $\mathrm{mg} / \mathrm{l}$ & - & 100 & 1254,00 & 26,64 & 97,87 & 1862,50 & 37,20 & 98,00 & 1252,00 & 6,10 & 99,51 \\
\hline Deterjen & $\mathrm{mg} / \mathrm{l}$ & & & & & & 76,41 & 0,11 & 99,86 & & & \\
\hline M\&Lemak & $\mathrm{mg} / \mathrm{l}$ & 10 & - & 2,20 & 3,60 & & & & & 4,80 & 2,60 & \\
\hline
\end{tabular}

Hasil uji laboratorium di atas menunjukkan bahwa penyisihan parameter TSS dapat maksimal, mencapai $95.47 \%$ hingga $99.56 \%$ dengan rata-rata penyisihan of $98.06 \%$. TSS di outlet tinggal $2-10 \mathrm{mg} / \mathrm{liter}$ yang jauh berada dibawah ambang batas $100 \mathrm{mg} / \mathrm{l}$ (Per.Men.LH), bahkan dibawah $30 \mathrm{mg} /$ liter berdasar standar yang disyaratkan untuk air tanaman oleh US Environmental Protection Agency [US EPA, 2000). Untuk parameter pH, semua percobaan sesuai kriteria baku mutu, yaitu antara 6-9. Penyisihan parameter BOD dapat maksimal, mencapai $97.98 \%$ hingga $99.58 \%$ dengan rata-rata penyisihan of $98.55 \%$. Kandungan BOD di outlet pada uji pertama 9,49mg/l dan uji ketiga 2,19 mg/l, besaran ini memenuhi standar mutu Per.Men LH dan PP untuk kelas IV sebagai air untuk mengairi tanaman. Namun, pada uji ke dua, meskipun penyisihan mencapai 97,98\%, besaran di outlet sebesar 17,20 mg/l. Besaran ini lebih besar dari yang disyaratkan untuk mengairi tanaman berdasar PP kelas IV, namun masih masuk standar US Environmental Protection Agency (US EPA, 2000). Untuk parameter COD, penyisihan mencapai $97,98 \%$ hingga $99,51 \%$ dengan rata-rata penyisihan mencapai 98,46\%. Konsentrasi COD di outlet untuk semua pengujian berada jauh dibawah $100 \mathrm{mg} / \mathrm{l}$ (mutu air kelas IV), bahkan dibawah 50mg/l (mutu air kelas III), maka efluen tersebut dapat digunakan untuk mengairi tanaman dan atau peruntukan lain yang 
mensyaratkan mutu air yang sama dengan kegunaan tersebut seperti air untuk bersih-bersih di outdoor atau untuk penggelontoran toilet. Penyisihan kandungan deterjen mencapai 99,86\%. Dengan demikian, deterjen yang selalu digunakan dalam kegiatan mencuci dapat dinetralisir melalui sistim lahan basah buatan. Untuk parameter minyak \& lemak, terjadi peningkatan pada sampel pertama dan penurunan pada sampel lainnya. Berdasar PP no. 82 tahun 2001, ambang batas minyak \& lemak dan deterjen tidak disyaratkan untuk air kelas IV. Air untuk tanaman merupakan pengeluaran terbesar dalam penyediaan kebutuhan air; dan air bagi tanaman tidak membutuhkan kualitas air setinggi kualitas untuk air baku untuk kebutuhan air minum (WHO, 2015). Dengan demikian, hasil olahan greywater dengan sistim CWs dapat mengurangi kebutuhan pasokan air bagi rumah tinggal maupun area komunal yang membutuhkan suplei air untuk tanaman/berkebun atau kebutuhan lain di out-door.

Tanaman air Cyperus papyrus yang digunakan dalam bak CWs hingga akhir penelitian mencapai ketinggian kurang lebih $100 \mathrm{~cm}$ seperti ditunjukkan pada Gambar 3a berikut. Tanaman tersebut termasuk tanaman dekoratif sehingga menciptakan green-view bagi lingkungannya. Hal tersebut merupakan salah satu kelebihan dari sistim pengolahan limbah dengan CWs dibandingkan dengan teknologi pengolahan limbah lainnya. Contoh penerapan CWs di rumah tinggal di Nepal dan di kawasan komunal di Kuching, Malaysia dapat dilihat pada gambar-gambar berikut.

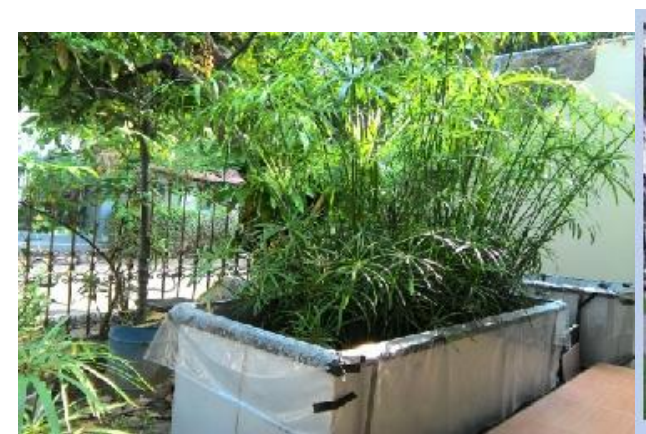

(a)

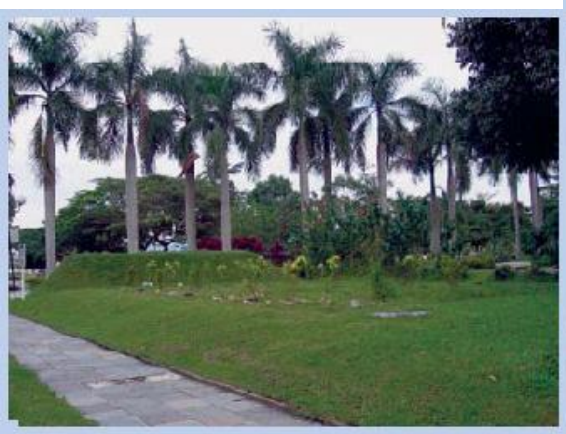

(b)

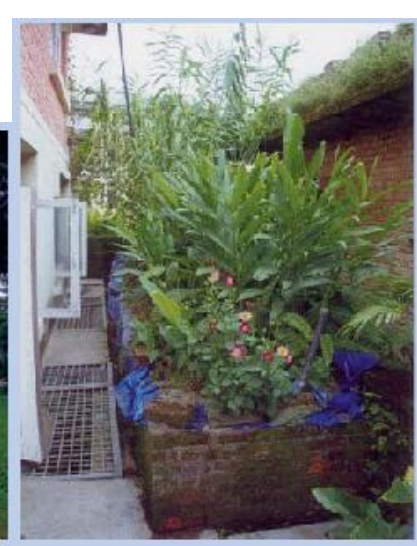

(c)

Gambar 3: (a) CWs dalam studi ini; (b) CWs di kawasan komunal di Kuching, Malaysia (Morel and Diener, 2006); (c) CWs di rumah tinggal di Nepal (Morel and Diener, 2006).

\section{KESIMPULAN}

Lahan Basah Buatan atau Constructed Wetlands (CWs) dengan media filter pasir dan kerikil serta tanaman air jenis Cyperus papyrus mampu mengolah limbah greywater rumah tangga (parameter TSS, pH, BOD, COD, Minyak \& Lemak, dan Deterjen) dengan prosentase penyisihan berkisar antara 95,47\%-99,89\%. Besaran konsentrasi polutan di oulet, yang merupakan hasil pengolahan greywater, memenuhi standar baku mutu Peraturan Menteri Lingkungan Hidup no. 4 tahun 2014, dan Peraturan Pemerintah no. 82 tahun 2001 kelas IV sebagai air untuk mengairi tanaman dan atau peruntukan lain yang mensyaratkan mutu air yang sama dengan kegunaan tersebut seperti untuk bersihbersih di outdoor dan atau untuk penggelontoran toilet. Air hasil pengolahan greywater tersebut jika dibuang ke saluran-saluran dapat menetralisir pencemaran air tanah dan air permukaan (sungai). Penggunaan tanaman air di dalam sistim Lahan Basah Buatan memberikan green space di rumah-rumah tunggal atau green public view di lahan-lahan komunal. Konsep Lahan Basah Buatan tidak hanya mengatasi problem pencemaran lingkungan, melainkan juga menyediakan sumber air non-konsumsi dan menciptakan kawasan hijau ramah lingkungan. Dibanding teknologi konvensional, sistim Lahan Basah Buatan lebih ekonomis, fleksibel, dan operasionalnya mudah.

\section{REFERENSI}

BLH - Badan Lingkungan Hidup. (2015). Pemantauan Kualitas air Sungai di Kota Surakarta. BLH Kota Surakarta.

Brix, H. and Arias, C.A. (2005). "The use of vertical flow constructed wetlands for on-site treatment of domestic wastewater: new Danish Guidelines". Ecological Engineering. 25. 491-500.

Brix, H. and Arias, C.A. (2007). "Twenty years experiences with constructed wetland system in Denmark - what did we learn?". Water Science \& Technology. Vol. 56, No. 3, 63-69.

Eriksson, E., Karina A., Mogen H., Anna L. (2002). “Characteristic of grey wastewater”. Urban Water 4, 85-104.

Elzein, Z., Abdou, A., Elgawad, A. (2016). "Constructed wetlands as asustainable wastewater treatment method in communities". Procedia Environmental Sciences. 34, 605-617 
Hoffman, H., Platzer, M., Winker, M., and Muench, E. (2011). Technology review of constructed wetlands. Deutsche Geselischatft fur Internationale Zusammenarbeit (GIZ) GmbH.

Hendrawan, D., Widanarko, S., Moersisik, S., Triweko, RW. (2013). "Evaluation of centralizrd WWTP and the need of communal WWTP in supporting community-based sanitation in Indonesia". European Scientific Journal. Vol.9, No.17, e-ISSN 1857-7431.

KLHK-Kementrian Lingkungan Hidup dan Kelautan. (2016). "Air sungai di Indonesia tercemar berat". Litbang Kompas. http://nationalgeographic.co.id/berita/2016/05. Diakses 1 September 2016.

Kadleck, RH and Wallace, SD. (2009). Treament Wetlands $2^{\text {nd }}$ Edition. CRC Press, Taylor \& Francis Group.

Kadlec, RH and Knight, RL. (1996). Treatment Wetlands. Lewis Publisher, New York.

Kivaisi, A. 2001. The Potential of Constructed Wetlands for Wastewater Treatment and Reuse in Developing Country. Ecology Engineering. 16 (4): 545-560

Langergraber, G. (2013). “Are constructed treatment wetlands sustainable sanitation solutions?” Water Science \& Technology. Vol 67, 2133-2140.

Morel, A and Diener, S. (2006). Greywater Management in Low and Middle Income Countries: Review of different treatment systems for households and neighbourhoods. Sandec Report No 14/6. Swiss Federal Institute of Aquatic Science and Technology. Dubendorf. Switzerland.

Merino-Solis, M., Villegas, E., De Anda, J., dan Lopez, A. (2015). "The effect of hydraulic retention time on the performance of an ecological wastewater treatment system". Water. 7, 1149-1163.

Pidou, M., Memon, FA, Stephenson, T., Jeffersen, B., Jeffrey, P. (2007). “Greywater recycling: treatment options and applications”. Proceeding of the Institution of Civil Engineering Sustainability. Vol 160. Issue ES3. Hal 119-131.

TWB (The World Bank). 2013. East Asia Pacific Region Urban Sanitatin Review: Indonesia Country Study. Australian Aid.

UN-HABITAT (2008). Constructed Wetlands Manual. United Nation Human Settlement Programme. ISBN Number: Vol.978-92-1-131963-7. www.unhabitat.org Diakses September 2015.

US EPA (2000). Constructed Wetlands Treatment of Municipal Wastewaters. EPA. 625/R-99/010. United States.

Vymazal, J. (2008). "Constructed wetlands for treatment: a Riview". Proceedings of Taal: The $12^{\text {th }}$ World Lake Conference: $965-980$.

Vymazal, J. (2010). Constructed Wetlands for Wasterwater Treatment, Water, 2, 530-549.

Vymazal, J. (2011). "Plants used in constructed wetlands with horizontal subsurface flow: a review". Hydrobiologia, 674, 133-156.

Wu, H., Zhang, J., Ngo, HH, Guo, W., Hu, Z., Liang, S., Fan, J., and Liu, H. (2015). “A review on the sustainability of constructed wetlands for waste water treatment: design and operation". Bioresources Technology. 175. 594-601.

WWAP (Word Water Assessment Programme). (2012). Managing Water under Uncertainty and Risk. UNESCO Report 4. Paris.

WHO - regional office for South-East Asia. (2004). Minimum Water Quantity Needs for Domestic Uses. Technical Note 9. www.who-int/water_sanitation_health. Diakses September 2015. 